\title{
DAILY RAINFALL VARIABILITY AT A LOCAL SCALE (1,000 ha), IN PIRACICABA, SP, BRAZIL, AND ITS IMPLICATIONS ON SOIL WATER RECHARGE
}

\author{
K. REICHARDT ${ }^{1,2,3}$; L.R. ANGELOCCI ${ }^{1,3}$; O.O.S. BACCHI ${ }^{2,3}$; J.E. PILOTTO ${ }^{2}$ \\ 'Departamento de Física e Meteorologia-ESALQ/USP, C.P. 9, CEP: 13418-900-Piracicaba,SP, Brazil \\ ${ }^{2}$ Centro de Energia Nuclear na Agricultura/USP, C.P. 96, CEP: 13400-970 Piracicaba, SP, Brazil \\ ${ }^{3}$ Bolsista do CNPq
}

\begin{abstract}
Daily rainfall variability at a local scale $(1,000 \mathrm{ha})$ was studied at Piracicaba, SP, Brazil, for the period of one year (1993-1994), in order to better understand the process of soil water recharge. Coefficients of variation of daily data for ten observation points varied from 2.2 to $169.3 \%$ and the variability was independent of rain type, i.e. whether convective, frontal or of other origin. Data were not related to separation distances between observation points and it is concluded that one observation point does not represent areas as far as 1,000 to 2,500 m apart, for daily, monthly or even quarterly averages. Yearly totals for the ten observation points presented a coefficient of variation as low as $3.06 \%$, indicating that all points can replace each other in annual terms.
\end{abstract}

Key Words: variability, rainfall, soil water recharge

\section{VARIABILIDADE DIÁRIA DA CHUVA EM UMA ESCALA LOCAL (1000 ha) EM PIRACICABA, SP, E SUAS IMPLICAÇÖES NA RECARGA DA ÁGUA DO SOLO}

\begin{abstract}
RESUMO: A variabilidade diária da chuva em uma escala local (1000 ha) foi estudada em Piracicaba,SP, Brasil, pelo período de um ano (1993-1994). Os coeficientes de variação de dados diários para dez pontos de observação variaram de 2,2 a $169,3 \%$ e a variabilidade independeu do tipo de chuva, isto é, se convectiva, frontal ou de outra origem. Os dados não apresentaram correlação com a distância entre os pontos de observação e concluiu-se que um ponto de observação não representa áreas distantes dele de 1000 a $2500 \mathrm{~m}$, para médias diárias, mensais ou mesmo trimestrais. Os totais anuais dos dez pontos apresentaram um coeficiente de variação de apenas $3,06 \%$, indicando que cada pouto pode representar qualquer outro em termos anuais.
\end{abstract}

Descritores: variabilidade, chuva, precipitação pluvial, recarga da água do solo

\section{INTRODUCTION}

It is well known that rainfall events in the tropics can have great variability over short distances. Commonly one observes that it is raining at a place and very close to it there is no rain. In many circunstances it is possible to observe on the ground the moving limit of the wetted front. These facts are extremely important in the planning of rainfall measurements in space and time.

This variability has great implications in the establishment of weather networks. Networks usually represent a collection of point data, the accuracy of each depending on the sensor characteristics, calibration, and proper exposure. Assuming as minimal the instrumental errors at each observation point, the selection of representative points is a difficult task. In Brazil rain gauge networks started only at the end of the last century, and up to date, in the most advanced part of the country, they represent a collection of points, each belonging to one county. As an example, in the network of the State of São Paulo, the county of Piracicaba with an area of 142,100 $\mathrm{ha}$, is represented by only one observation point. How well does this point represent the county?

Piracicaba, having an advanced sugarcane agro-industry, has several other rainfall observation points; these, however, are not considered part of the official state network. Their data will be used in a later study, to characterize the daily rainfall space variability on a medium space scale. The present study considers this variability on a smaller space scale, here called 
"local", which represents an area of the order of 1,000 ha, which is about the size of the Campus of the University of São Paulo at Piracicaba. Since it is common to rain in one part of the campus and in another not, it is important to characterize this variability.

The most frequently weather variable referred to in the literature is rainfall. Of special interest are the network design studies of EAGLESON (1967), MORIN et al. (1979) and SHIH (1982). Among the reports on rainfall spatial variability, HUBBARD (1994) is a study of several weather variables including rainfall, using data of 24 stations of a medium scale network in USA. He concludes that to monitor precipitation at a level to explain $>90 \%$ of the variation between sites, the spacing between them should be less than $5 \mathrm{~km}$.

With respect to the effect of rainfall variability on soil water changes and on consequent yield, on a local basis, no reports have been found. VILLAGRA et al. (1995) present an analysis on the effect of soil variability in estimating evapotranspiration from the water balance equation. Since their experimental plot is a strip of $5 \times 125$ $\mathrm{m}^{2}$, they considered the rainfall as being constant, although the rain gauge was located about $200 \mathrm{~m}$ from the center of their plot. Which would be the minimum size of an experimental area in order to be allowed to consider precipitation constant? This paper represents an effort to answer these kind of questions.

\section{MATERIAL AND METHODS}

Nine rainfall collection points were choosen as randomly as possible within the area of the Campus of the University of São Paulo, in the county of Piracicaba, SP, Brazil ( $22^{\circ} 44^{\prime}$ 'S; $43^{\circ} 33^{\prime}$ $W$ ), at an altitude of $580 \mathrm{~m}$ above sea level, $250 \mathrm{~km}$ inside the continent. The tenth collection point, considered as a standard, is the official weather station of the campus, for which 78 years of rainfall data are available. Figure 1 indicates the distribution of the collection points, which cover an area of about 1,000 ha. The closest and the farest points from the standard are, respectively, 990 and $2,550 \mathrm{~m}$ apart.

The raingauges choosen have a collection area of $300 \mathrm{~cm}^{2}$, installed $1.5 \mathrm{~m}$ above ground level, being free of any obstacle in a circle of at least $20 \mathrm{~m}$ radius. Their accuracy of measurement is $0.1 \mathrm{~mm}$. Data collection started November 1993 and ended October 1994, completing one full year.

Since it is permitted to calculate the statistical moments of any population without knowing their distribution, data were used to calculate means, standard deviations, and coefficients of variation, without fitting them to any distribution. Correlation between data of each observation point and the standard observation point was also performed.

\section{RESULTS AND DISCUSSION}

For the kind of study here focused it is important to the reader to observe the raw data, in order to obtain a feeling of the variability that can be expected. Table 1 presents the raw data for the period of one year, for all ten observation points, together with their means, standard deviations, and coefficients of variation.

Data for the first eight collection dates in TABLE 1 are incomplete because not all rain gauges were installed at the same date. Other missing data correspond to days in which the rain gauge tap was found open. This problem could not be avoided because several locations permit the access of the people. Zeros are days in which there was no rain at the specific observation point. Daily C.V. varied from $2.2 \%$ to $169.3 \%$. From the 87 rainy days of the year, 15 present a C.V. below $10 \%$ and 8 above $100 \%$. For the days with C.V. below $10 \%$, precipitations were indistinctly of low and high intensities, however for the days with C.V. above $100 \%$,precipitations were all of very low intensity, most of them including several zeros, i.e. with several observations very close to the accuracy of the rain gauges. During the collection period it was also observed that the magnitude of the variability was independent of the type of rain, i.e. whether it is of convective, front or other origin.

In order to calculate the cumulative precipitation for the whole observation period, missing data were replaced by the respective daily averages. HUBBARD (1994) replaced missing data by weighted averages using five nearest stations and the inverse separation distance law. Since the data of this study did not present any correlation with distance, simple averages were taken to replace missing data, however only for the purpose of estimating yearly totals. These values are presented at the bottom of Table 1. Minimum and maximum values are, respectively, 1,020 and 1,141 $\mathrm{mm}$, and the coefficient of variation is $\mathbf{3 . 0 6}$. 


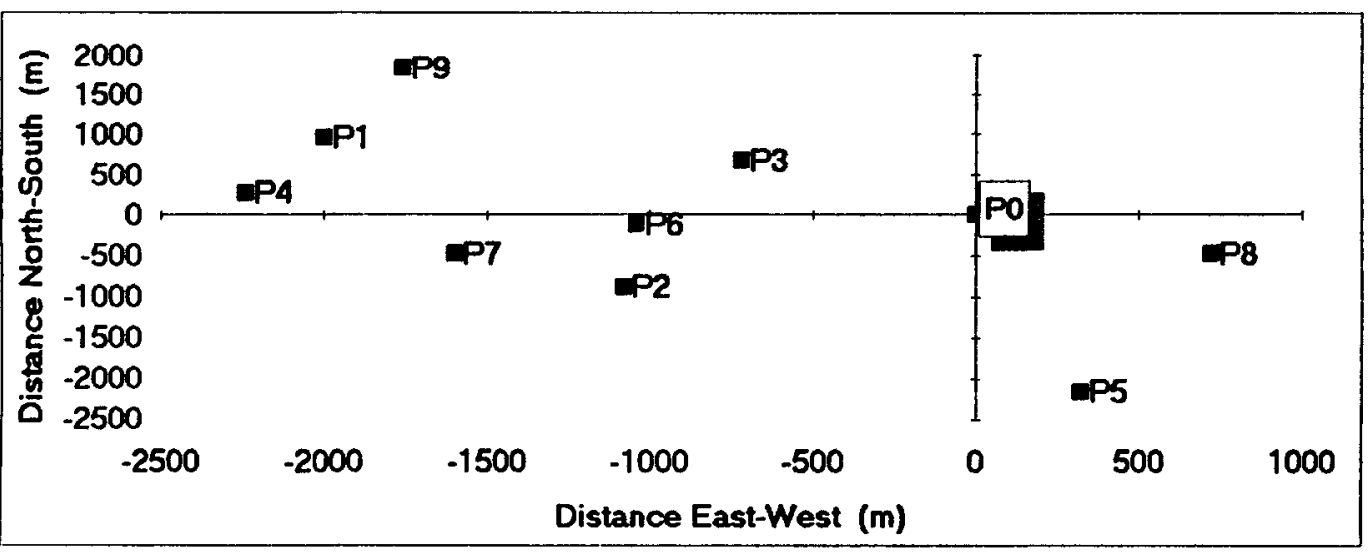

Figure 1 - Location of the obsevation points: P1 = Pivot at Fazenda Areão; P2 = Museum "Luiz de Queiroz"; P3 =Faculty Club Restaurant; P4 = Center for Nuclear Energy in Agriculture; P5 = SINFESALQ Recreation Area; P6=Crop Production Experimental Area; P7 =Center for Biotechnology; $\quad$ P8=Pasture; $\quad$ P9=Piracicaba Astronomic Observatory; $\quad P 0=E S A L Q$ Meteorological Station (standard).

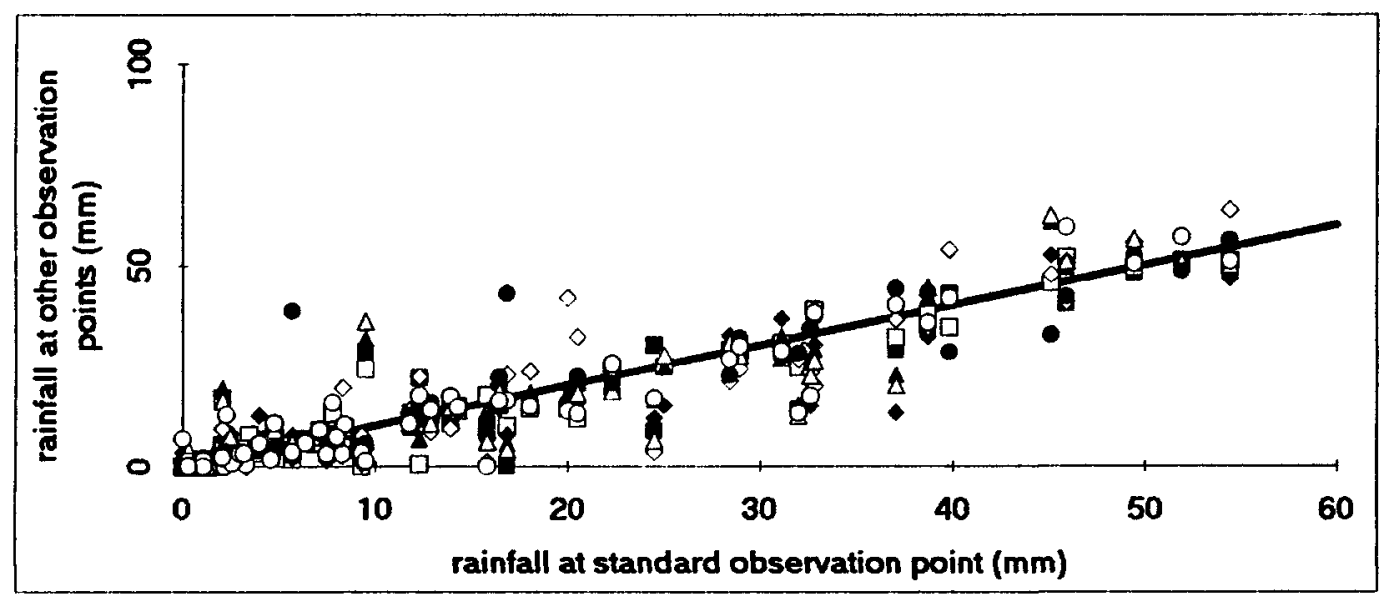

Figure 2 - Regression of rainfall data at each observation point as a function of standard point data

Another convenient form to observe the overall variability is presented in Figure 2 , in which data of each observation point is plotted against the standard observation point. Although data present a great variability, they are distributed along the 1:1 regression line, as expected. 
TABLE 1 - Rainfall data (mm) for all ten observation points over the whole observation period (November 1993 - October 1994). Blancs are missing data and zeroes are no rain.

\begin{tabular}{|c|c|c|c|c|c|c|c|c|c|c|c|c|c|}
\hline Date & $\mathbf{P 1}$ & $\mathbf{P 2}$ & P3 & P4 & P5 & P6 & P7 & $\mathbf{P 8}$ & $P 9$ & P0 & Ave. & S.D. & c.v. \\
\hline Nov. 2 & 6,2 & & 5,6 & 6,1 & 5,6 & & & & & 6,9 & 6,08 & 0,54 & 8,81 \\
\hline Nov. 6 & 11,5 & 11,8 & 11,8 & 12,2 & & & & & & 12 & 11,86 & 0,26 & 2,20 \\
\hline Nov. 7 & 9 & 8,8 & 8,8 & 8,6 & 7 & & & & & 8,1 & 8,38 & 0,74 & 8,88 \\
\hline Nov. 17 & 7 & 6,8 & 3,2 & 12,6 & 4,5 & & & & & 4 & 6,35 & 3,42 & 53,89 \\
\hline Nov. 18 & 1 & 0,8 & 0,2 & 1,6 & 0,4 & & & & & 1,2 & 0,87 & 0,52 & 59,58 \\
\hline Nov. 22 & 10,2 & & 24,6 & 15 & & 24,8 & 27,6 & & & 25 & 21,20 & 6,92 & 32,64 \\
\hline Nov. 23 & 3 & 3 & 2,8 & 3 & 3 & 2,4 & 2,6 & & & 2,5 & 2,79 & 0,25 & 9,08 \\
\hline Nov. 25 & 5,2 & 3,6 & 7,8 & 3,8 & 2,4 & 4,8 & 3,4 & & & 3,5 & 4,31 & 1,65 & 38,31 \\
\hline Nov. 26 & 30,6 & 29 & & 32,4 & 21,2 & 27,8 & 30,8 & 22,6 & 26,6 & 28,4 & 27,71 & 3,74 & 13,49 \\
\hline Dec. 3 & 13,6 & 0 & 10 & 7,8 & 22,8 & 5,6 & 4,2 & 42,8 & 16,3 & 16,8 & 13,99 & 12,19 & 87,13 \\
\hline Dec. 4 & 1,2 & 5,8 & 0 & 0,6 & 7,6 & 5,2 & 2,4 & 4,4 & 3,4 & 9,3 & 3,99 & 3,06 & 76,66 \\
\hline Dec. 8 & 10,6 & & 7,4 & 11 & & 7,4 & 9 & 3,8 & 10,6 & 4,8 & 8,08 & 2,73 & 33,78 \\
\hline Dec. 11 & 17,4 & & 14,2 & 15,2 & 41,8 & 18,6 & 14,8 & 13,6 & 13,8 & 20 & 18,82 & 8,91 & 47,32 \\
\hline Dec. 15 & 2,2 & 3 & & 3,2 & 7,6 & 2,6 & 2,8 & 4,2 & 1,8 & 4,6 & 3,56 & 1,76 & 49,42 \\
\hline Dec. 17 & 15,8 & 18,8 & 15,2 & 14,2 & 22,2 & 21 & 18,4 & 22,2 & 16,2 & 16,4 & 18,04 & 2,94 & 16,32 \\
\hline Dec. 19 & 12,8 & 12 & 12,8 & 11,2 & 8,5 & 12 & 10,6 & 15,8 & 14 & 12,9 & 12,26 & 1,96 & 16,02 \\
\hline Dec. 26 & 15,2 & 20,5 & 11,8 & 16 & 32,1 & 17,5 & 18,2 & 22,4 & 13,1 & 20,5 & 18,73 & 5,77 & 30,82 \\
\hline Dec. 28 & 27,8 & 27,2 & 28,4 & 29,5 & 24,3 & 28,4 & 27,5 & 31,8 & 29,6 & 28,9 & 28,34 & 1,94 & 6,84 \\
\hline Dec. 30 & 10,8 & 9,6 & 13,2 & 10,4 & 14,4 & 11,6 & 10,5 & 11 & 10,9 & 11,9 & 11,43 & 1,43 & 12,49 \\
\hline Jan. 3 & 3 & 3,6 & 3,4 & 3,7 & 3,5 & 3,3 & 3,3 & 3,2 & 3 & 2,9 & 3,29 & 0,27 & 8,16 \\
\hline Jan. 13 & 48,6 & 51,3 & & 49,4 & 49,3 & 49,9 & 50,6 & 48,5 & 57 & 51,9 & 50,72 & 2,62 & 5,17 \\
\hline Jan. 18 & 5 & 3,7 & 3,9 & 4,1 & 3,9 & 3,7 & 3,3 & 3,8 & 5,7 & 4 & 4,11 & 0,71 & 17,22 \\
\hline Jan. 19 & 2 & 1,7 & 1,8 & 3 & 0,2 & 2,1 & 4 & 0,6 & 1,3 & 0,3 & 1,70 & 1,19 & 70,21 \\
\hline Jan. 22 & 3,3 & 6 & 1,8 & 5 & 3,1 & 4,3 & 6,3 & 1 & 12,7 & 2,3 & 4,58 & 3,35 & 73,05 \\
\hline Jan. 25 & 11,8 & 8,6 & 9,5 & 10,7 & 9,8 & 8,8 & 9,6 & 10 & 10,3 & 8,4 & 9,75 & 1,03 & 10,60 \\
\hline Jan. 27 & 45,5 & 48,9 & 51 & 46,7 & 63,7 & 49,3 & 50,1 & 56,3 & 51 & 54,4 & 51,69 & 5,30 & 10,26 \\
\hline Jan. 28 & 2,7 & 4 & 4,8 & 1,5 & 3,7 & 5,6 & 4,2 & 7 & 3,1 & 7,5 & 4,41 & 1,88 & 42,52 \\
\hline Jan. 31 & 0 & 0 & 0,7 & 0 & 0,2 & 0,3 & 0 & 2,1 & 0 & 1,6 & 0,49 & 0,76 & 154,96 \\
\hline Feb. 5 & 41 & 42,8 & 34,5 & 53,6 & 54 & 41,8 & 42,8 & 28,4 & 41,8 & 39,8 & 42,05 & 7,65 & 18,20 \\
\hline Feb. 7 & 15,5 & 15,3 & 14,4 & 15,5 & 23,7 & 18,5 & 16,8 & 16,2 & 14,9 & 18 & 16,88 & 2,73 & 16,19 \\
\hline Feb. 9 & 11,7 & 28,6 & 24,2 & 30,1 & 4,4 & 31,8 & 36 & 5,6 & 1,3 & 9,5 & 18,32 & 13,08 & 71,41 \\
\hline Feb. 12 & 0 & 1,2 & 4,3 & 0,6 & 0 & 2,8 & 2,1 & 2,9 & 0,5 & 3,3 & 1,77 & 1,52 & 85,81 \\
\hline Feb. 13 & 0 & 8,9 & 17,7 & 6,7 & 1,1 & 14 & 6,2 & 11,2 & o & 15,8 & 8,16 & 6,52 & 79,87 \\
\hline Feb. 15 & o & 0 & 0,1 & 0,2 & 0 & 0,4 & 0,2 & 0,3 & 0 & 0,3 & 0,15 & 0,15 & 100,62 \\
\hline Feb. 16 & 0,1 & 0 & 0,2 & 0,4 & 0 & 0,4 & 0,3 & 0,3 & 0,1 & 0,3 & 0,21 & 0,15 & 72,57 \\
\hline Feb. 19 & 18,8 & 22 & 0,5 & 13,2 & 22,3 & 6,8 & 17,7 & 15,1 & 17,6 & 12,3 & 14,63 & 6,81 & 46,55 \\
\hline Feb. 20 & 16,6 & & 28,5 & 15,1 & 23,5 & 26 & 22,6 & 34 & 17,5 & 32,6 & 24,04 & 6,86 & 28,54 \\
\hline Feb. 22 & 4,7 & 6 & 5,3 & 2,6 & 19,6 & 4,2 & 4,3 & 10,2 & 3,1 & 8,3 & 6,83 & 5,05 & 73,90 \\
\hline Feb. 26 & 0 & 0,4 & 0,5 & 0,3 & 0 & 0,6 & 0 & 2,1 & 0,5 & 1,1 & 0,55 & 0,64 & 116,66 \\
\hline Feb. 27 & 7,2 & & 1,7 & 7,8 & 2,2 & 3,1 & 6 & 38,5 & 3,5 & 5,7 & 8,41 & 11,49 & 136,61 \\
\hline
\end{tabular}




\begin{tabular}{|c|c|c|c|c|c|c|c|c|c|c|c|c|c|}
\hline Feb. 28 & 14,7 & & 13,1 & 7 & 3,1 & 8,3 & 5,9 & 8 & 15,8 & 7,8 & 9,30 & 4,27 & 45,95 \\
\hline Mar. 1 & 35,4 & & 38,7 & 30,1 & 20,1 & 29 & 26,3 & 37,2 & 38,1 & 32,8 & 31,97 & 6,21 & 19,41 \\
\hline Mar. 7 & 0 & & 1 & 0 & 0,5 & 0,7 & 0 & 0,7 & 0 & 1,4 & 0,48 & 0,52 & 108,14 \\
\hline Mar. 11 & 51,4 & & 45,5 & 52,5 & 47,6 & 61 & 62,4 & 32,6 & & 45,1 & 49,76 & 9,53 & 19,14 \\
\hline Mar. 17 & 0 & 1,1 & 1,3 & 2,5 & 3 & 3,1 & 2,8 & 3,7 & 0 & 2,2 & 1,97 & 1,30 & 66,23 \\
\hline Mar. 19 & 60,5 & 40,3 & 52,1 & 51,1 & 40,8 & 49,7 & 51 & 42,2 & 59,5 & 45,9 & 49,31 & 7,14 & 14,48 \\
\hline Mar. 20 & 16,8 & 10,5 & 15,3 & 14,4 & 9,3 & 15,6 & 14,8 & 16,2 & 17,3 & 13,9 & 14,41 & 2,61 & 18,11 \\
\hline Mar. 21 & 4,5 & 6,7 & 3 & 8,3 & 5,1 & 4,8 & 7,4 & 1,8 & 2,1 & 2,5 & 4,62 & 2,29 & 49,62 \\
\hline Mar. 24 & 0 & 1,2 & 0,8 & 0,3 & 0 & 0,8 & 0,8 & 0,5 & 0 & 0,7 & 0,51 & 0,42 & 82,39 \\
\hline Mar. 25 & 38,5 & 34,4 & 37,7 & 32,1 & 34,6 & 42,3 & 44,5 & 43,1 & 35,6 & 38,7 & 38,15 & 4,12 & 10,79 \\
\hline Mar. 26 & 0 & 3,3 & 2,5 & 1,8 & 0,5 & 1,6 & 1,7 & 1,4 & 0 & 2 & 1,48 & 1,06 & 71,71 \\
\hline Mar. 31 & 37,7 & 28,8 & 32 & 13,3 & 36,4 & 22,8 & 20,3 & 44,1 & 40,1 & 37 & 31,25 & 9,80 & 31,37 \\
\hline Apr. 1 & 0 & 0,6 & 1,2 & 0 & 0 & 0,3 & 0 & 0,5 & 0 & 0,4 & 0,30 & 0,39 & 131,47 \\
\hline Apr. 6 & 0 & 0,8 & 1,4 & 1,5 & 0 & 2,4 & 2,5 & 1,8 & 0 & 2,2 & 1,26 & 1,00 & 79,65 \\
\hline Apr. 13 & 1,8 & 1,5 & 3,5 & 2 & 1,1 & 2,2 & 2,3 & 2,7 & 1,7 & 2,8 & 2,16 & 0,70 & 32,53 \\
\hline Apr. 18 & 1,8 & 3,4 & 5,2 & 6,8 & 9,4 & 19,6 & 3,2 & 2 & 2 & 2,1 & 5,55 & 5,53 & 99,64 \\
\hline Apr. 21 & 53,1 & 48 & 49,5 & 56 & 55,8 & 50,6 & 56,6 & 52,3 & 50,5 & 49,4 & 52,18 & 3,09 & 5,92 \\
\hline Apr. 22 & 11,8 & 14,3 & 24,6 & 12,4 & 26,6 & 15,3 & 12,6 & 28 & 13,3 & 32 & 19,09 & 7,77 & 40,71 \\
\hline Apr. 24 & 0 & 0,8 & 0,4 & 0,5 & 0 & 0.5 & 0,3 & 1,1 & 0 & 0,8 & 0,44 & 0,38 & 86,51 \\
\hline Apr. 25 & 5,5 & 0 & 0 & 3,3 & 0 & 0 & 0 & 0 & 6,7 & 0 & 1,55 & 2,62 & 169,34 \\
\hline Apr. 26 & 15,5 & 8,8 & 29,9 & 12 & 3,5 & 16,6 & 6,4 & 30,2 & 16,8 & 24,5 & 16,42 & 9,33 & 56,80 \\
\hline May 13 & 6 & 6,6 & 6,7 & 6,2 & 6,3 & 7 & 6,3 & 6,4 & 5,8 & 6,4 & 6,37 & 0,34 & 5,39 \\
\hline May 14 & 1,8 & 2,1 & 2,2 & 2,4 & 2,2 & 1,9 & 2 & 2,3 & 2,3 & 2,2 & 2,14 & 0,19 & 8,87 \\
\hline May 15 & 27,1 & 30,7 & 30,4 & 36,6 & 30,7 & 32,2 & 27,1 & 27,3 & 28,5 & 31,1 & 30,17 & 2,92 & 9,68 \\
\hline May 22 & 0 & 0,2 & 0,7 & 0,5 & 0,1 & 0,5 & 0,8 & 0,5 & 0,2 & 0,6 & 0,41 & 0,27 & 65,50 \\
\hline May 23 & 1,2 & 0,9 & 1,1 & 1,4 & 1,3 & 1 & 1,1 & 0,9 & 1,5 & 1,1 & 1,15 & 0,20 & 17,51 \\
\hline May 26 & 2,8 & 3 & 2,5 & 2,2 & 1,5 & 2,6 & 2,5 & 3 & 0,7 & 2,6 & 2,34 & 0,72 & 30,83 \\
\hline May 27 & 10,3 & 11,4 & 11,5 & 11 & 10,6 & 11,6 & 10,7 & 12,5 & 10,5 & 11,8 & 11,19 & 0,69 & 6,17 \\
\hline Jun. 4 & 0 & 0,5 & 1,3 & 1,4 & 2 & 0,9 & 1,3 & 0,9 & 0 & 1,1 & 0,94 & 0,63 & 67,13 \\
\hline Jun. 8 & 3,4 & 3,1 & 3,4 & 3 & 3,1 & 3,3 & 2,9 & 3 & 3,2 & 3 & 3,14 & 0,18 & 5,66 \\
\hline Jun. 21 & 3,4 & 3,5 & 3,2 & 3,5 & 3,5 & 3,4 & 2,8 & 3,3 & 3,2 & 3,2 & 3,30 & 0,22 & 6,55 \\
\hline Jun. 22 & 14,9 & 15 & 14,3 & 14,8 & 14,8 & 13,7 & 13,9 & 14 & 14,7 & 14,3 & 14,44 & 0,46 & 3,20 \\
\hline Jun. 24 & 5,3 & 4,8 & 9 & 6,5 & 8,1 & 8,5 & 5,6 & 6 & 7,2 & 8 & 6,90 & 1,47 & 21,25 \\
\hline Jun. 25 & 8,3 & 9,1 & 7 & 6,5 & 7,2 & 7,3 & 7,5 & 8,3 & 9 & 7,1 & 7,73 & 0,89 & 11,49 \\
\hline Jul. 8 & 2 & 3,1 & 17 & 17,4 & 2,5 & 17,1 & 16,3 & 1,6 & 2,2 & 2,1 & 8,13 & 7,61 & 93,55 \\
\hline Jul. 22 & 15,8 & 18,6 & 24,1 & 23,2 & 22 & 19,4 & 18,8 & 20,6 & 25,4 & 22,3 & 21,02 & 2,92 & 13,90 \\
\hline Jul. 23 & 0,1 & 0,4 & 0,4 & 0,5 & 0,1 & 0,3 & 0,3 & 0,2 & 0 & 0,3 & 0,26 & 0,16 & 60,68 \\
\hline Sep. 30 & 1,2 & & & 1,5 & & & & 0,5 & 1,7 & 0,5 & 1,08 & 0,56 & 51,72 \\
\hline Oct. 1 & 3,5 & 2,2 & 3,2 & 6,4 & 0 & 1,7 & 1,4 & 0,6 & 2,3 & 0,6 & 2,19 & 1,86 & 85,00 \\
\hline
\end{tabular}




\begin{tabular}{lccccccccccccc}
\hline Oct. 16 & 38,8 & & 38,7 & 38,3 & 19,3 & 28,6 & 22 & 25,5 & 39,3 & 26,6 & 30,79 & 8,02 & 26,06 \\
Oct. 20 & 3,5 & & 4,5 & 4,4 & 4,7 & 2,8 & 2 & 5,7 & 3,3 & 5,5 & 4,04 & 1,24 & 30,54 \\
Oct. 22 & 2,2 & 3,2 & 1,2 & 3,5 & 2,5 & 3,6 & 5,1 & 2,3 & 1,8 & 2,5 & 2,79 & 1,10 & 39,50 \\
Oct. 24 & 11,5 & 10,2 & 10,7 & 8,8 & 11,8 & 12,1 & 9,6 & 10,3 & 9 & 9,9 & 10,39 & 1,14 & 10,93 \\
Oct. 26 & 21,5 & 32,2 & 26,3 & 31,7 & 36,4 & 28,6 & 34,1 & 22,5 & 33,7 & 24,5 & 29,15 & 5,23 & 17,95 \\
Oct. 27 & 29,7 & 32,5 & 34,9 & 30,2 & 27,1 & 33 & 32,2 & 35,5 & 40,1 & 36,6 & 33,18 & 3,76 & 11,34 \\
Oct. 28 & 16,7 & 23,6 & 20,7 & 21,1 & 16,3 & 18,6 & 19,5 & 22,3 & 11 & 19,1 & 18,89 & 3,59 & 19,02 \\
Oct. 30 & 0 & 0,6 & 0 & 0,3 & 0 & 0,5 & 2,1 & 1,1 & 0 & 0,3 & 0,49 & 0,67 & 136,21 \\
& & & & & & & & & & & & & \\
accum. & 1024 & 1043 & 1103 & 1075 & 1087 & 1109 & 1073 & 1141 & 1069 & 1106 & 1083,8 & 33,20 & 3,06 \\
\hline
\end{tabular}

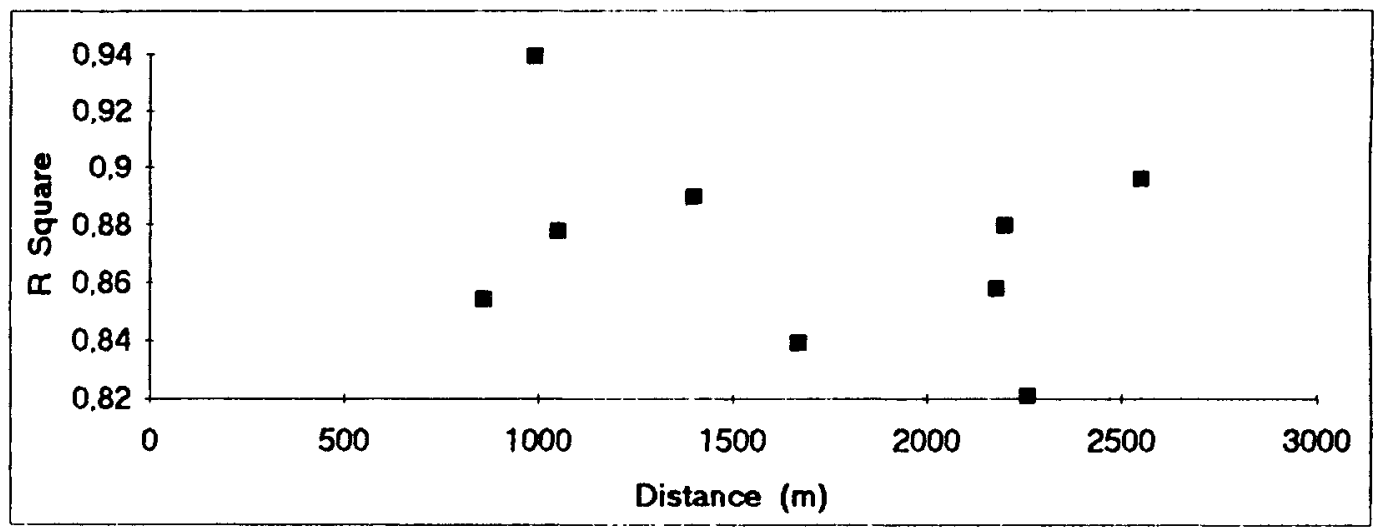

Figure 3 - Correlation between data of pairs of observation points with distances

To quantify the spatial variability RODDA (1962) and HOPKINS (1979) plotted the correlation coefficient between data of pairs of observation points, with respective separation distances. This approach was also here used, and is presented in Figure 3. As can be seen, there is no correlation with distance. This fact indicates that, although there is a great variability among observation sites, this variability has a random characteristic. The fact that a more dense cloud is positioned over some specific rain gauges is a completely randomic process at the studied scale. Therefore it is not possible to estimate at which distance a given observation explains a given fraction of the respective observation at the standard observation point, as HUBBARD (1994) did. The results however show the importance of the variability in space. Authors avoided to take monthly and quarterly averages because the number of rainfall days is very variable, and because the available data correspond only to one year of observation. Data, however, clearly indicate that rainfall data collected at the standard observation point do not represent areas as far as 1,000 to $2,500 \mathrm{~m}$ apart, for daily, monthly or even quarterly averages, which is the case of annual crops. For yearly totals the coefficient of variation was $3.06 \%$, indicating that any of the observation point can replace the standard observation one.

\section{CONCLUSIONS}

Coefficients of variation of daily rainfall data collected at ten obsevation sites distributed randomly over an area of about $1,000 \mathrm{ha}$, and over the period of one year (1993 - 1994), at Piracicaba, varied from 2.2 to $169.3 \%$. For days with C.V. below $10 \%$, precipitations were indistinctly of low 
and high intensities, however for days with C.V. above $100 \%$, precipitations were all of low intensity, most of them including several zeros. The magnitude of the variability is independent on the rain type, i.e. whether convective, frontal or of other origin. Correlations between data from pairs of observation sites were not related to separation distances, indicating that at this scale of distances the variability is a randomic process. The observed variability shows that rainfall data collected at one observation point does not represent areas as far as 1,000 to $2,500 \mathrm{~m}$ apart, for daily, monthly or even quarterly averages. For yearly totals the coefficient of variation was $3.06 \%$, indicating that all observation points can replace each other.

\section{REFERENCES}

EAGLESON, P.S. Optimum density of rainfall networks. Water Resources Research, Washington, v.3, p.1021-1033, 1967.

HOPKINS, J.S. The spatial variability of daily temperature and sunshine over uniform terrain. Meteorological Magazine, London,n.106, p.278-292, 1979.
HUBBARD, K.G. Spatial variability of daily weather variables in the high plains of the USA. Agricultural and Forest Meteorology, Amsterdam, v.68, p.29-41, 1994.

MORIN, G.; FORTIN, J.; SOCHANSKA, W.; WILHITE, D.A. Use of principal component analysis to identify homogeneous precipitation stations for optimal interpolation. Water Resources Research, Washington, v.15, p.1841-1850, 1979.

RODDA, J.C. An objective method for the assessment of aereal rainfall amounts. Weather, Reading, v.17, p.54-59, 1962.

SHIH, S.F. Rainfall variation analysis and optimization of gauging systems. Water Resource Research, Washington, v.18, p.1269-1277, 1982.

VILLAGRA, M.M.; BACCHI, O.O.S.; TUON, R.L.; REICHARDT, $K$. Difficulties of estimating evapotranspiration from the water balance equation. Agriculture For Meteorology, Amsterdam, v.72, p.317-325, 1995 .

Entregue para publicação em 14.12.94

Aceito para publicação em 10.02.95 